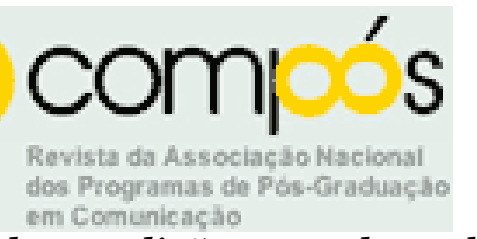

Este artigo foi publicado na edição 1, em dezembro de 2004, da revista eletrônica e-compós: http://www.compos.org.br/e-compos

\title{
DISCUTIR AS RELAÇÕES E NÃO A EVENTUAL FALTA DE IDENTIDADE DA COMUNICAÇÃO SOCIAL COM OUTROS CAMPOS DE CONHECIMENTO'
}

\section{Prof. Dr. Antonio Hohlfeldt ${ }^{2}$}

Famecos - PUCRS

Antes de mais nada, devo cumprimentar à Profa. Dra. Dione Moura, do Programa de Pós-Graduação em Comunicação Social da UNB, pela organização desse IV Interprogramas. E digo isso com a experiência de quem, dos quatro seminários até aqui realizados, inclusive este de que participamos, estive presente em três deles. Deixamos para trás as lamentações e as preocupações em saber se constituímos ou não um campo específico do conhecimento humano para buscarmos desenhar as relações que nosso campo de conhecimento desenvolve com outros campos de conhecimento. Avançamos, pois, em nossos debates, sobretudo porque o diálogo desenvolvido nesse Interprogramas evidencia coerência e criatividade:

partimos de um hipotético e potencial diálogo da Comunicação com a Teoria Social, levando-se em conta a existência das representações coletivas,

\footnotetext{
${ }^{1}$ Texto apresentado no painel do IV INTERPROGRAMAS da COMPÓS, promovido pelo Programa de PósGraduação em Comunicação Social da UNB- Universidade de Brasília, em Brasília, dias 28 e 29 de outubro de 2004.

${ }^{2}$ Doutor em Letras pela PUCRS, ex-Coordenador do Programa de Pós-Graduação em Comunicação Social da FAMECOS/PUCRS, professor de "Teorias da Comunicação" e de "Comunicação e Opinião pública", naquele mesmo Programa.
} 
a que temos de acrescentar, logo, representações coletivas simbólicas, para chegarmos ao debate sobre as representações coletivas simbólicas, mediadas coletivamente, em que se constitui a Comunicação Social. Refletimos sobre linguagens atuais, estéticas e/ou midiáticas, e, muito especialmente, a respeito de uma dessas representações, que é o jornalismo.

Até pela pressão do tempo - recebemos os textos nos últimos dias antes desse encontro e, embora os tenhamos lido antecipadamente, e acompanhado com atenção as apresentações e os debates propiciados enfrentamos a dificuldade de resumir, em algumas grandes linhas, toda a imensa riqueza do que nos foi aqui apresentado. De qualquer modo, algumas observações bastante gerais podem ser registradas, ao mesmo tempo em que algumas indagações também nos surgiram.

A primeira impressão que levo desse nosso diálogo é uma modificação no status de relacionamento entre a Comunicação Social e as demais ciências sociais. Modificamos nossa percepção, com toda a certeza: não mais vislumbramos a Comunicação Social enquanto numa dependência, um campo dependente de outros campos, ou de uma relação hierarquizada, para chegarmos a um contexto de dialogia plena, onde a Comunicação Social se encontra em patamar semelhante às demais ciências sociais, dialogando com elas de igual para igual, chegando mesmo a contribuir com elas com alguns conceitos e algumas concepções fundamentais.

Se ainda não sabemos concretamente quem somos e onde estamos, certamente já conseguimos mapear alguns loci de referencialidade e indicar ao menos algumas coisas que não somos:

1. o reconhecimento da importância que a bomba atômica de Hiroshima, atualizada pelo 11 de setembro de Nova York, teve para a percepção sobre a importância crescente que as tecnologias adquirem para a sociedade contemporânea, como indica Cláudio Bertolli Filho;

2. a queda do Muro de Berlim é outro acontecimento que influi decisivamente sobre a contemporaneidade, na medida em que consolida o capitalismo internacional;

3. a emergência da globalização nos obriga a visualizar o entorno sob nova ótica, embora não impeça a percepção da regionalização; antes pelo 
contrário, a regionalização surge como uma espécie de contraponto, complementação e objetivação daquela mesma globalização;

4. a presença irrefutável do que Armand Dreifuss chamou de teleinfocomputrônica, ou seja, a conjugação de diferentes e múltiplas tecnologias que se conjugam em ações concertadas, gerando

5. uma espécie de onipresença da Comunicação Social em toda a organização social humana, em especial através do chamado jornalismo, o que leva a humanidade à experiência daquela aldeia global antecipada, na década de 1960, por Marshall McLuhan, ainda que não se trate nem de hierarquizar nem de discutir o mérito de tais realidades, mas apenas, no momento, constatá-las, buscar compreendê-las e tratar de avaliá-las, tarefa maior a que nossos Programas de PósGraduação devem se dedicar, quer em nossas reuniões de interprogramas, quer em nossas atividades internas.

Experimentamos o temor e, ao mesmo tempo, a admiração por tal realidade, pois modificamos profundamente algumas práticas profissionais, como o jornalismo, e nos damos conta da fantástica abertura e responsabilidade, inclusive e sobretudo ética, que a Comunicação Social assumiu junto à sociedade humana, nesse horizonte que não é fixo, não está acabado nem concluído, mas é, apenas, um esboço e, como tal, encontra-se em constante movimento e mutação.

Creio que se deva registrar, igualmente, certa avaliação consensual entre nós segundo a qual os meios de comunicação, mais do que os veículos de informação, constituem-se em produtores de sentido, como aqui destacaram Valdir José Morigi e Gottfried Stockinger. Eles vêm se constituindo em constructos universais ou universalizantes, mas também esses sentidos não são nem definitivos, nem fixos ou imóveis. Pelo contrário, tais representações se mosram extremamente flexíveis e mutáveis, no tempo e no espaço, contemporâneas em diferentes formatações, que refletem a velocidade e a variedade mesma de nossas próprias percepções, causando-nos estresse, medo, intranqüilidade, sentimento de estranhamento e angústia.

A midiatização, como a denominamos, é, de um lado, uma das tantas articulações entre as diferentes e contraditórias representações sociais que 
circulam entre nós, mas é, também, aquela que mais articula a todas as demais, ganhando, assim, uma função fantasticamente importante na realidade atual.

Tal constatação, presente em nossos diálogos, pode suscitar temor diante de uma eventual ditadura, de um pensamento único que impediria nossa liberdade de ver e de pensar - contudo, constata-se que há muito mais brechas do que poderíamos supor à primeira vista, diante dessa realidade. Os próprios princípios constitutivos de tal realidade permitem - quase necessitam - sua contestação, sua recriação, sua inversão, num movimento que é tão pluralista quanto universalista: esse princípio, expresso por Valdir José Morigi, foi aqui retomado por um sem-número de expositores, dentre os quais permito-me citar José Gatti, quando defende a interdisciplinaridade ou a transdisciplinaridade, conforme o debate aberto por Maria Immacolata Vassalo Lopes.

José Gatti, aliás, introduziu a perspectiva de pensarmos a mídia não enquanto um meio, apenas, ou um veículo, mas enquanto um ambiente. Deixamos de pensar os meios de comunicação apenas como um menino de recados entre diversos modos e campos de percepção, mas colocamo-los enquanto uma espécie de articulador a partir do qual praticamente todas as atividades humanas se desenvolvem, retomando, talvez, aquela velha assertiva de Aristóteles, segundo a qual o homem é um ser animal, social e racional, com que iniciava suas discussões sobre a política, valorizando a sociabilidade e, por conseqüência, a comunicabilidade, ao contrário de seu antecessor, Platão.

Maria Immacolatta, por seu turno, discutiu cuidadosamente o sentido contextualizado e histórico da transdisciplinaridade, bem como a necessidade de rompermos com tal paradigma no momento atual . Ora, se compreendermos a comunicação enquanto uma hiper-realidade, evidentemente precisamos reconhecer e admitir como intrínseca a ela a dificuldade de reduzi-la a um determinado território. E se, como relembra Maria Immacolatta, precisamos ter clareza quanto ao objeto e aos métodos específicos da comunicação, só alcançaremos realizar essa tarefa se chegamos a conhecer, analisar e identificar os procedimentos específicos através dos quais se manifesta a comunicação social: é do particular, ou melhor, dos particulares, na medida em que se tornarem gerais, pela multipresença em diferentes interações simbólicas, que chegaremos ao geral. 
Parece-me que é isso que defende Edgar Morin, em seu paradigma da complexidade: mais que uma situação estática, a complexidade é um conjunto dinâmico que se espalha em movimentos contraditórios mas complementares, por todos os aspectos da realidade. Se há um fenômeno contemporâneo que pode traduzir e concretizar, com absoluta naturalidade, tal assertiva, é a Comunicação Social. Pode-se afirmar que é próprio da Comunicação Social a complexidade, porque ela não é só uma coisa, nem múltiplas: ela está uma e outras, neste momento, mas logo depois pode estar e ser outras mais, sempre em movimento, eis que é um processo, que reflete, se reflete, envolve e produz outras realidades, à medida em que participa da percepção de realidades complexas e as constitui, simultâneamente.

Contraditoriamente, a comunicação social, tal como a teoria social, tem, como uma de suas principais funções, a interação social, a ordem e a organização do caos mas, ao mesmo tempo, ela é essencialmente subversiva, provocadora de quebra dos paradigmas estabelecidos, proponente e construtora de novas realidades. Basta lembrar a virtualidade levada ao paroxismo, através da chamada teleinfocomputrônica, bem como das redes internacionais de computadores, o que diz bem da ambigüidade e da complexidade da comunicação, que se traduz, especialmente, pela interatividade.

$\mathrm{Na}$ análise das concretizações específicas da mídia, temos, primeiramente, um mapeamento de Selma Regina Nunes Oliveira, que abre caminho para uma série de estudos sobre a economia política dessas novas linguagens e suportes, ou pelas reflexões trazidas a respeito das relações entre as artes e a mídia, especialmente o status da chamada artemídia, por Arlindo Machado e César Guimarães. O primeiro chama a atenção especialmente para aquele aspecto de subversão a que a arte aspira, contrário à perspectiva massificadora das novas tecnologias, que buscam a quantificação máxima, produtora de lucratividade. Mesmo assim, Arlindo Machado reconhece a existência de brechas para o contra ataque e as valoriza, mostrando que o estranhamento, característico da arte, apesar de todas as dificuldades, inclusive técnicas, termina por acontecer. 
Quanto a César Guimarães, ao introduzir os conceitos de real performático e de pathos do real, também abre caminho para um debate essencial, que é encontrar o locus específico da comunicação. Sua análise tanto nos devolve a uma célebre discussão da nouvelle vague francesa e do cinema novo brasileiro dos anos 50 e 60, quanto às possibilidades do plano seqüência, por exemplo, no caso do cinema - e da televisão, que ele reconhece como o principal midium hoje presente em nosso cotidiano. Sua perspectiva reforça a idéia, mais tarde explorada por Luiz Gonzaga Motta, de que o sentido midiático não se encontra propriamente na mensagem - como inclusive quiz McLuhan, quando enfatizou sua forma e seu canal - mas no receptor, o que se concretiza na medida em que se valoriza a relação midiática e não o objeto midiático, ampliando a aplicação de um conceito desenvolvido por Robert Jauss, na teoria da recepção.

Assim como se tem defendido a transdisciplinaridade, há que se valorizar a multiculturalidade. É isso o que faz Renato Cordeiro Gomes, em seu estudo sobre as megalópoles. Caracterizadas pela fragmentação e a alteridade, a elas a comunicação é chamada para, de um lado, auxiliar na construção de um espaço mínimo - físico e imaginário - de convivência, e, por outro, garantir a plena expressão de todas aquelas alteridades, colocando-as em patamares democraticamente semelhantes, certamente o que permitirá tais diálogos, na medida em que evita a constituição de falsos imaginários, destrutivos e preconceituosos. Propõe ele, assim, a partir dos estudos de Walter Mignolo, uma perspectiva de cosmopolitismo que se opõe à de globalização, já que a primeira pressupõe a dialogia, e a segunda a elimina.

Sidney Fereira Leite fez uma extensa e criativa exposição sobre as idéias de Douglas Kellner, um dos autores constantemente citados durante esses debates, e que se tornou referência tanto para as teorias sociais quanto para as perspectivas da mídia contemporânea em nosso mundo, retomando, mas de modo mais complexo e dinâmico, as perspectivas da Escola de Frankfurt.

Já Angela Prysthon desenvolveu a perspectiva dos estudos de pós colonialismo, tão presentes entre os cientistas anglo-falantes, para defender o multiculturalismo como uma postura essencial para que possamos conviver no mundo contemporâneo. Daí a importância, para ela, dos Estudos Culturais, ainda 
que reconheça também os riscos que êles contêm, se não trabalhados sob uma perspectiva crítica. Essa revisão a que procede a autora, assim, chama-nos a atenção para a crescente descentralização, em constituição, de centros mundiais de estudos ou para os quais o mundo ocidental dirige seus olhares. Isso ocorreria porque boa parte das grandes megalópoles atuais não estão situadas no chamado I Mundo, mas, sim, ao sul do planeta. Ângela Pryston salienta, então, a importância que os estudos culturais, tais como se têm constituído na própria América Latina, ou seja, fora do centro, através de Néstor Garcia Canclini, sobretudo, possuem, na medida em que imbricam sua perspectiva com aqueles primeiros textos a respeito das teorias sociais e das representações que se constituem, buscando ultrapassar a questão da subalternidade.

Numa espécie de repercussão prática dessa perspectiva, o estudo apresentado por um grupo de pesquisadores da Universidade Federal do Rio de Janeiro é um excelente alerta de como não se deve deixar que as coisas aconteçam. De um lado, a prática midiática preconceituosa e, de outro, o olhar atento e a crítica imediata do pesquisador, a evidenciar a contribuição que a instituição universitária, e os Programas de Pós Graduação em Comunicação podem, efetivamente, dar à sociedade brasileira: surge-nos a possibilidade de que a Universidade auxilie na emersão de novas práticas discursivas, ultrapassando estereótipos e preconceitos, potencialidade que se constitui em um dos grandes desafios que todos nós precisamos enfrentar e ultrapassar.

Aliás, permito-me registrar que esse balanço entre teoria e prática, entre a reflexão mais abstrata e a aplicação prática desses princípios, a situações ou mídias específicas, pode ser indicado como uma das novidades e um dos grandes avanços deste Interprogramas.

Depois de revisar as perspectivas de enquadramento do jornalismo enquanto estudo de caráter universitário, Elias Machado faz um levantamento de fases da prática jornalística em nosso país, de linhas de pesquisa existentes em nossos Programas de Pós Graduação dirigidas ao jornalismo e, então, passa a discutir a existência e a necessidade - ou não - de metodologias adequadas ao campo, perspectiva essa que se junta, portanto, àquela mais ampla, sobre os objetos e as metodologias adequadas à comunicação social. 
Mostra ele que a bibliografia é escassa. Mais que isso, sugere, como possibilidade de estudo, uma diferenciação entre os estudos de jornalismo e as teorias de jornalismo: os estudos de jornalismo dedicar-se-iam aos produtos e práticas, enquanto as teorias desdobrariam a especificidade do jornalismo. Seu ponto de vista é que a atual mescla entre as duas tendências faz com que o uso indiscriminado de bibliografias e metodologias de outras áreas, que não a específica do jornalismo, não contribua para o desenho dessa desejada especificidade. Ao contrário, tal distinção permitiria, segundo ele, um salto de qualidade fundamental, que se refletiria, de imediato, nas próprias práticas e, sobretudo, na sua compreensão, tanto por parte dos profissionais, quanto da cidadania em geral.

Também defendendo a multidisciplinaridade, Elias Machado reconhece que o jornalismo não é nem um campo de conhecimento, nem produz saberes relevantes para estabelecer parcerias com práticas e pesquisas de outras áreas. Defendendo que o jornalismo é uma prática social que precisa ser conhecida, entendida e valorizada, o autor entende a necessidade do desenvolvimento de metodologias específicas para a sua análise. Para ele, a multidisciplinaridade, além da formação de redes de pesquisadores, sociabilizando as descobertas realizadas, facilitaria, dinamizaria e ampliaria a compreensão do jornalismo: a multidisciplinaridade deveria ocorrer especialmente nos estudos sobre a área tecnológica, para que se possa bem avaliar e compreender os novos suportes e sua influência sobre as práticas, posição, aliás, que há muito foi igualmente defendida por Jesús Martin Barbero a respeito da comunicação em geral. De outro lado, a socialização das descobertas entre os pares ampliaria - dinamizando - o aprendizado e as descobertas sobre o campo.

Afonso Albuquerque, depois de relatar os trabalhos desenvolvidos em seu Programa, parte de algumas de suas pesquisas para buscar entender a identidade do campo, em nosso país e, ao mesmo tempo, definir algumas metodologias de pesquisa. Sua conclusão parece reiterar o que se tem dito e tem nos preocupado a respeito da própria comunicação: a fragmentação do campo e, por conseqüência, a falta de identidade; a incompreensão, mesmo entre os profissionais, sobre o que seja a prática jornalística e a impossibilidade de uma 
reflexão mais conseqüente a respeito de sua significação social. Defende ele uma maior aproximação entre as empresas e os pesquisadores, o que se aproxima, de certo modo, à posição de Elias Machado, quando defende maior proximidade entre a tecnologia e a teoria. De modo geral, contudo, sua conclusão é de que jornalistas ainda são profissionais sem identidade.

Mostrando que a chamada ágora pública contemporânea é o jornalismo, Alfredo Eurico Vizeu Pereira Jr. busca resgatar alguns elementos da teoria da notícia, na medida em que o jornalismo é uma daquelas práticas referidas pela teoria social, capazes de constituir uma representação social. Não só por ser uma prática técnica (ou tecnológica), mas também por produzir uma representação simbólica, que é a notícia, o jornalismo constrói um conhecimento social específico e diferenciado de outros conhecimentos, baseado nos chamados valores notícia que orientam a noticiabilidade dos acontecimentos: unem-se assim as duas pontas dos trabalhos aqui apresentados, desde aquele primeiro, de Cláudio Bertolli Filho e este, na medida em que Luiz Gonzaga Motta depois promoverá um recorte mais específico a respeito de como a notícia se concretiza, através da narratividade.

Em seu texto, Luiz Gonzaga Motta, seguindo tendência de outros pesquisadores, desloca a importância da significação da notícia, do texto da mesma, para a leitura que dela realiza o receptor, retomando assim, aliás, perspectiva da estética de Benedetto Crocce, que considera como sujeito estético, portanto, o autor propriamente dito, de uma obra de arte, não o artista, teoricamente seu criador, mas o receptor, que lhe dá sentido.

Depois de repassar algumas teorias vinculadas aos estudos literários, mostrando aquilo que elas teriam de contribuição e de adaptabilidade a uma teoria do jornalismo, Gonzaga Motta fixa sua atenção na idéia da novidade e da descontinuidade, presente tanto no conceito de narratividade, de Carlos Reis e demais integrantes do Grupo de Entrevernes, ecoando a perspectiva de Greimas, quanto no conceito de tempo humano que Paul Ricoeur desenvolve, mostrando que esse tempo é um articulador entre o passado e o futuro e que, portanto, não é um estado mas, sim, um movimento ou uma função.

É pela intriga que os fatos ganham sentido, mas a intriga (o modo pelo qual os acontecimentos são ligados, separados ou relacionados) não se 
encontra no emissor ou no relato, mas estaria situada no receptor, que faz seu próprio recorte do conjunto múltiplo e cotidiano que lhe é apresentado. Dessa perspectiva avultaria uma potencial abordagem ética e moral do jornalismo, propiciada por uma tal valorização do receptor, na medida em que esse receptor compara a realidade narrada e a realidade que ele gostaria que existisse ou ocorresse. A perspectiva, evidentemente, aproxima-se da teoria da recepção, tal como a desenvolveram Hans Robert Jauss e Wolfgang Iser. Neste sentido, o jornalismo não se constitui apenas enquanto um relato sobre o mundo, mas potencializa uma compreensão e uma valorização desse mesmo universo, atuando ora como consolidador do conjunto social, pela crítica que faz da realidade, ora enquanto documentador do novo, na medida em que a notícia, embora narrada quase sempre através de verbos no pretérito, refere fatos do presente, mesmo que este presente seja sempre fugidio e provisório.

Feita esta síntese, como se pedira, passemos agora a algumas observações finais que tentam responder, em parte, à pergunta-tema "a) que problemas de relação comunicação e sociedade foram abordados pelos palestrantes; b) que tipo de respostas foram oferecidas ao debate social e c) que tipo de diálogo a comunicação tem estabelecido com o campo da teoria social, desde o ponto de vista das perspectivas apresentadas?"

1. sinteticamente, pode-se dizer que se modificou substancialmente a presença dos estudos sobre a comunicação e, por conseqüência, a compreensão a respeito de sua contextualização e de suas relações com outros campos de conhecimento;

2. essa mudança se caracteriza, em meu entendimento, pelo distanciamento de uma relação de dependência e subserviência da comunicação social a outras disciplinas, para a de um equilíbrio e convívio, em que a troca, e até mesmo a preeminência da comunicação pode e deve ser reconhecida;

3. fica evidente a relação da comunicação com a teoria social, mas dos trabalhos aqui apresentados emergem relações com a historiografia, com a teoria da literatura, com a política, com a psicologia - e especialmente a psicologia social com a sociologia, com a estética, etc.; 
4. se é exata a constatação de que a comunicação social permeia toda a realidade humana, que tipo de objeto e, por conseqüência, que tipo de metodologia devemos buscar para a comunicação? Longe de nos angustiarmos com certas indefinições, eu diria que é fundamental distinguirmos e refletirmos sobre o específico da comunicação. Não se pode exigir para um campo, que é amplo o suficiente para dialogar com uma multiplicidade tão grande de outros campos de conhecimento, os mesmos princípios e métodos aplicáveis a um campo mais explícito e reduzido. Assim, creio que,

a) buscando, com clareza, ver o que não somos, em hipótese alguma e

b) valorizando no particular aquilo que possa ser ampliado para o geral, isto é, começando pelo estudo das práticas para chegar à formulação das hipóteses e das teorias, identificando o que é comum e consensual em cada prática, para generalizá-la enquanto partícipe do campo, conseguiremos responder ao que nos angustia.

5. neste sentido, é importante verificarmos certa consensualidade na bibliografia consultada por aqueles que aqui relataram suas pesquisas e apresentaram suas reflexões; mais que isso, o diálogo que, gradualmente, se estabelece entre todos nós: cresceu muito a referência dos pesquisadores brasileiros a outros pesquisadores brasileiros: isso fica evidente na leitura daqueles textos que relatam ou se referem sobretudo a questões mais práticas, como que a evidenciar que o estudo de práticas é básico para que se reconheça e constitua, portanto, o objeto ou os objetos teóricos da comunicação.

Sinteticamente, assim, podemos afirmar que os problemas de relação entre comunicação e sociedade abordados nesse Interprograma foram aqueles que evidenciam a importância da comunicação social entre um ambiente capaz de produzir sentidos que são depois universalizados socialmente, ampliando conhecimento e consciência, problematizando realizadas e projetando no futuro alternativas variadas.

Quanto às respostas dadas, parece-se serem elas sempre abertas, voltadas para a análise e a reflexão, sem se pretenderem respostas definitivas. São 
respostas dialógicas, que articulam e se articulam com outros campos de conhecimento humano.

Por fim, o tipo de diálogo que a comunicação social tem estabelecido com o da teoria social é o diálogo entre semelhantes. Hoje em dia, ambos os campos trocam informações e conceitos, inter-iluminam-se e, por isso mesmo, apresentam-se de maneira complementar. 